\section{Quantity Theory of Money Redux? Will Inflation Be the Legacy of Quantitative Easing?}

\section{William R. Cline}

William R. Cline, senior fellow, has been associated with the Peterson Institute for International Economics since its inception in 1981. His numerous publications include Managing the Euro Area Debt Crisis (2014), Financial Globalization, Economic Growth, and the Crisis of 2007-09 (2010), and The United States as a Debtor Nation (2005).

Author's note: I thank Abir Varma for research assistance. For comments on an earlier draft, I thank without implicating my colleagues Joseph Gagnon, Paolo Mauro, Avinash Persaud, David Stockton, Edwin M. Truman, and Ángel Ubide.

\section{(C) Peterson Institute for International Economics. All rights reserved.}

Since the onset of the Federal Reserve's unconventional program of large scale asset purchases, known as quantitative easing (QE), some economists and financial practitioners have feared that the consequent buildup of the Fed's balance sheet could lead to a large expansion of the money supply, and that such an increase could cause a sharp rise in inflation. ${ }^{1}$ The Federal

\footnotetext{
1. In public and investor perceptions, "a recurrent theme is the idea that $\mathrm{QE}$ creates a danger of surging inflation. The policy involves creating new money ... and there is a long history of economic theory that argues that rapid increase in the money supply eventually leads to higher inflation." (Andrew Walker, "Has Quantitative Easing Worked in the US?" BBC News, October 30, 2014.) In mid-2009, economist Arthur Laffer warned that because of the unprecedented rise in the monetary base associated with quantitative easing, "we can expect rapidly rising prices and much, much higher interest rates over the next four or five years." (Arthur B. Laffer, "Get Ready for Inflation and Higher Interest Rates," Wall Street Journal, June 11, 2009.) Writing for the St. Louis Fed, Daniel Thornton $(2010,1)$ worried that "current excess reserves could create a massive increase in the money supply should banks significantly
}

Reserve implemented QE to address the need for additional monetary easing in the Great Recession once interest rates had already reached the zero bound. Other major economies have also adopted QE, first the United Kingdom and subsequently Japan and the euro area. So far fears about induced inflation have not been validated. If anything, the problem has been too little rather than too much inflation, as judged against the Fed's benchmark targets. ${ }^{2}$

This Policy Brief examines the basis for the original concerns about inflation in terms of the classic quantity theory of money, which holds that inflation occurs when the money supply expands more rapidly than warranted by increases in real production. The Brieffirst reviews the US experience and shows that whereas rapid money growth might have been a plausible explanation of inflation in the 1960s through the early 1980s, thereafter the data have not supported such an explanation. It then shows that the quantity theory of money has not really been put to the test after the Great Recession, because the Federal Reserve's balance sheet has not translated into money available to the public in the usual fashion. The Brief concludes that the most likely aftermath of quantitative easing remains one of benign price behavior. It warns, however, that if nascent inflationary conditions were to materialize, the Federal Reserve would need to manage adroitly the large amounts of banks' excess reserves that have accumulated as a consequence of $\mathrm{QE}$ in order to limit inflationary pressures.

So far QE has not caused a massive increase in the money supply that matters for inflation; the money base has indeed risen sharply, but the broad money supply has not. The reason is that excess bank reserves held at the Federal Reserve have risen sharply but have not increased the money supply available to the public. Correspondingly, it turns out that the lack of inflationary

increase their lending or investing ... $[\mathrm{S}] \mathrm{uch} \mathrm{a}[\mathrm{n}]$ increase ... would be inflationary."

2. The Federal Open Market Committee (FOMC) has pursued a target of 2 percent inflation as measured by the personal consumption expenditures price index (Federal Reserve 2015i). From the fourth quarter of 2008 to the fourth quarter of 2014, the actual pace of inflation using this measure has been an average of only 1.49 percent annually (calculated from Federal Reserve Bank of St. Louis 2015). 
pressure reflects a collapse not in so-called "velocity" in the quantity theory of money, but instead in the so-called "money multiplier" relating the effective money supply in the economy to the money base of currency plus bank reserves at the Federal Reserve. By implication, the legacy of quantitative easing would only turn out to be high inflation in the future if two conditions were to materialize: first, a breakdown in the Fed's control that permitted a rapid resurgence of the money multiplier and money available to the public; and second, a reversal of the pattern of the past three decades to an earlier pattern in which rapid growth in the money supply was associated with high inflation.

It seems likely that the Federal Reserve will instead be able to avoid an inflationary aftermath of $\mathrm{QE}$ by raising interest rates as needed to keep excess reserves from spilling out into the money supply available to the public. However, because quantitative easing has all along involved navigating in uncharted waters, inflation is better seen as a low-probability rather than a no-probability outcome. It is possible to imagine scenarios in which fears of excessively rapid increases in interest rates, and/ or political pressures to avoid much higher interest rates (in part because of fiscal consequences for the interest on public debt), could lead the Federal Reserve to set interest rates at levels that prove insufficiently attractive to banks for them to keep the excess reserves intact. Moreover, as discussed below, setting a far higher reserve requirement as the alternative instrument is not an option under current legislation that limits the required reserve ratio.

\section{QUANTITY THEORY OF MONEY AND INFLATION}

Most closely identified with 20th-century economists Milton Friedman and Irving Fisher, the quantity theory of money is also present in the writings of classical economists such as David Hume, David Ricardo, and John Stuart Mill (Blaug 1968). In the United States in the 1960s through the early 1980s, the correlation between inflation and the expansion of the money supply was sufficiently close that there was ample room for heated controversy between monetarists, who emphasized the inflationary consequences of money supply growth, and Keynesians, who instead invoked the Phillips curve linkage of low unemployment to high inflation and saw money growth as demand induced rather than causal for inflation. In recent decades, however, the empirical relationship of inflation to money growth has broken down, as discussed below.

By the late 1990s, in both the United States and United Kingdom the dominant framework for monetary policy had shifted decisively away from the quantity of money as a determinant of inflation (Congdon 2006, 1). However, the quantity theory of money remains alive and well in the euro area, where "monetary analysis" based on longer-term trends in money aggregates is one of two "pillars" underpinning monetary policy. The other pillar is "economic analysis" focused on shorter-term real and financial conditions (ECB 2015a).

According to the quantity theory, the price level for the economy as a whole, $P$, multiplied by the quantity of output available, $Q$ (which product equals the market value of output during the year), should equal the stock of money available, $M$, times the "velocity" or number of times that money turns over in purchases during the course of the year, $V:^{3}$

1) $P Q=M V$

If velocity is constant, as quantity theory tends to assume, then it follows directly that the sum of inflation and the percent change in real output should equal the percent change in the money supply:

2) $\dot{P}+\dot{Q}=\dot{M}$

where the overdot represents proportional change. ${ }^{4}$ The first term in the second equation is inflation, the percent rise in the price level.

Considering that the proportionate change in output is also the real growth rate, or $g$, and moving this term to the right-hand side, it follows that inflation should equal the excess of the percent rise in money supply over the real growth rate:

3) $\dot{P}=\dot{M}-g$

The proper measure of the money supply to use for gauging inflationary pressure has long been a subject of debate. Although the initial formulation in terms of transactions might suggest a narrow monetary aggregate measure, such as M1 in the United States (currency held by the public plus checkable deposits), the potential for easy conversion argues for broader measures. ${ }^{5}$ Whatever the aggregate measured, high inflation as

3. See Blaug $(1968,616)$. Fisher's original formulation used "T" for transactions instead of $Q$ and did not necessarily refer to a period of one year.

4. There is also an interaction term between the two terms on the left-hand side, but with normal amounts of inflation and output growth it is small enough to be ignored. (That is: $[1+a] \times[1+b]=1+a+b+a b$.)

5. In the United States, M2 includes M1 plus savings deposits, time deposits under $\$ 100,000$, and household money-market deposit accounts. M3 additionally included large-denomination time deposits, institutionally-held money-market accounts, repurchase agreement liabilities, and eurodollars. However, statistical reporting on M3 was discontinued by the Federal Reserve in 2006. For a contemporary critique of that decision and an argument favoring the broader concept, especially because of its relevance for asset prices, see Congdon (2006). 
the outcome of excessive printing of money is a textbook explanation of experience in banana-republic (or Weimar Republic) economies. It also can be seen as fitting the experience in the United States in the 1960s and 1970s, when there was a steady acceleration in inflation that accompanied a rise in the money supply.

In the early 1970s, the Federal Reserve published data for five different monetary aggregates, and from 1974 to 1987 the Federal Open Market Committee (FOMC) specified "ranges of tolerance" for M1 and the broader M2. ${ }^{6}$ Although for a time the Federal Reserve staff applied the "P-star" inflation forecasting model using M2 for the quantity of money and estimates of long-term potential output and velocity to predict long-term inflation trends, financial innovation eventually caused the stability of the economic relationships based on M2 to break down, and the FOMC stopped setting target ranges for money aggregates in 2000 (Bernanke 2006). The influence of quantity theory may be seen as having peaked in October 1979 when the Federal Reserve under then-chairman Paul Volcker in effect shifted from targeting the federal funds rate to targeting the quantity of money in order to exert greater control over high inflation, which reached 13.5 percent in 1980 (International Monetary Fund [IMF] 2015a). ${ }^{7}$ The federal funds rate surged from about 8 percent in 1978 to about 18 percent in 1981, before the Fed shifted back to a focus on interest rates in the fall of 1982 in the midst of what at the time was the worst recession since the Great Depression (Federal Reserve Bank of San Francisco 2003). Bernanke (2006, 2) observes that monetary and credit aggregates "have not played a central role in the formulation of US monetary policy since that time ...."

\section{REVERSAL FROM THE 1960S AND 1970 S TO THE LAST THREE DECADES}

As shown in figure 1, during the period 1962-84, annual US inflation as measured by the GDP deflator (vertical axis) roughly tracked the average excess growth in the broad money supply over real GDP growth during the year in question and the previous year (horizontal axis). ${ }^{8}$ This period includes the Great Inflation, typically dated from the mid-1960s or early

6. The passel of alternative aggregates reflected what Edwin M. Truman reports was called the "search for P-star" inside the Federal Reserve at the time. Avinash Persaud notes that there was a similar quest in the United Kingdom. (By communication with the author.)

7. The change adopted an operating procedure based on management of nonborrowed reserves, with the intention of focusing policy on controlling the growth of M1 and M2 (Bernanke 2006).

8. Until 2005 the data for year-over-year percent changes in money supply refer to M3; thereafter, they refer to corresponding percentage changes in the IMF's roughly comparable "broad money" series (IMF 2015a). 1970s through the early 1980s. A simple linear regression for this period shows a statistically significant coefficient of 0.54 for inflation against the excess of money growth over real GDP growth. However, the degree of explanation is moderate (adjusted $\mathrm{R}^{2}$ of 0.36 ), and the size of the coefficient is only about one-half as large as that required by the quantity theory (unity). In contrast to this loose positive relationship, the bottom panel in the figure shows that in 1985-2013 there was a negative relationship between inflation and average excess money growth. ${ }^{9}$ The quantity theory of money broke down as an explanation of inflation.

\section{In 1985-2013 there was a negative relationship between inflation and}

\section{average excess money growth. The \\ quantity theory of money broke down as an explanation of inflation.}

Sargent and Surico (2011) show this reversal between these two periods. They construct a dynamic stochastic general equilibrium (DSGE) model involving a new Keynesian Phillips curve for inflation and Taylor rule for monetary policy. They find that "a monetary policy shift towards a significantly more aggressive anti-inflationary stance" can generate results that cause instability in the quantity equation's relationship of inflation to money supply. ${ }^{10}$

At a more intuitive level, however, it is useful to see the two periods shown in figure 1 as a shift from dominance on the side of money supply (top panel) to dominance on the side of money demand (bottom panel). Namely, in a period in which disinflation is reducing the opportunity cost of holding money, one would expect an outward shift in the demand for money. Lower inflation rates would then tend to be associated with larger increases in the observed stock of money. Inflation fell systematically from the mid-1980s to the mid-1990s, so it is reasonable that the demand for money balances would have successively increased. ${ }^{11}$

9. In the bottom panel, the regression coefficient has turned negative $(-0.12)$ and is statistically significant.

10. Sargent and Surico $(2011,122)$. Nonetheless, the authors formulate their DSGE model in a fashion that rules out a direct causal role from money to inflation. Money demand is a dependent variable (it appears on the left-hand side of their relevant equation, not the right-hand side), but it can behave in a manner that gives the impression of a direct relationship with inflation.

11. All five of the observations at the extreme right are in years associated with current or lagged recession (2001-02, 2007-09), when the real growth subtracted in the excess money variable is low, and low interest rates boost 
Figure 1 US inflation versus excess of broad money growth over output growth
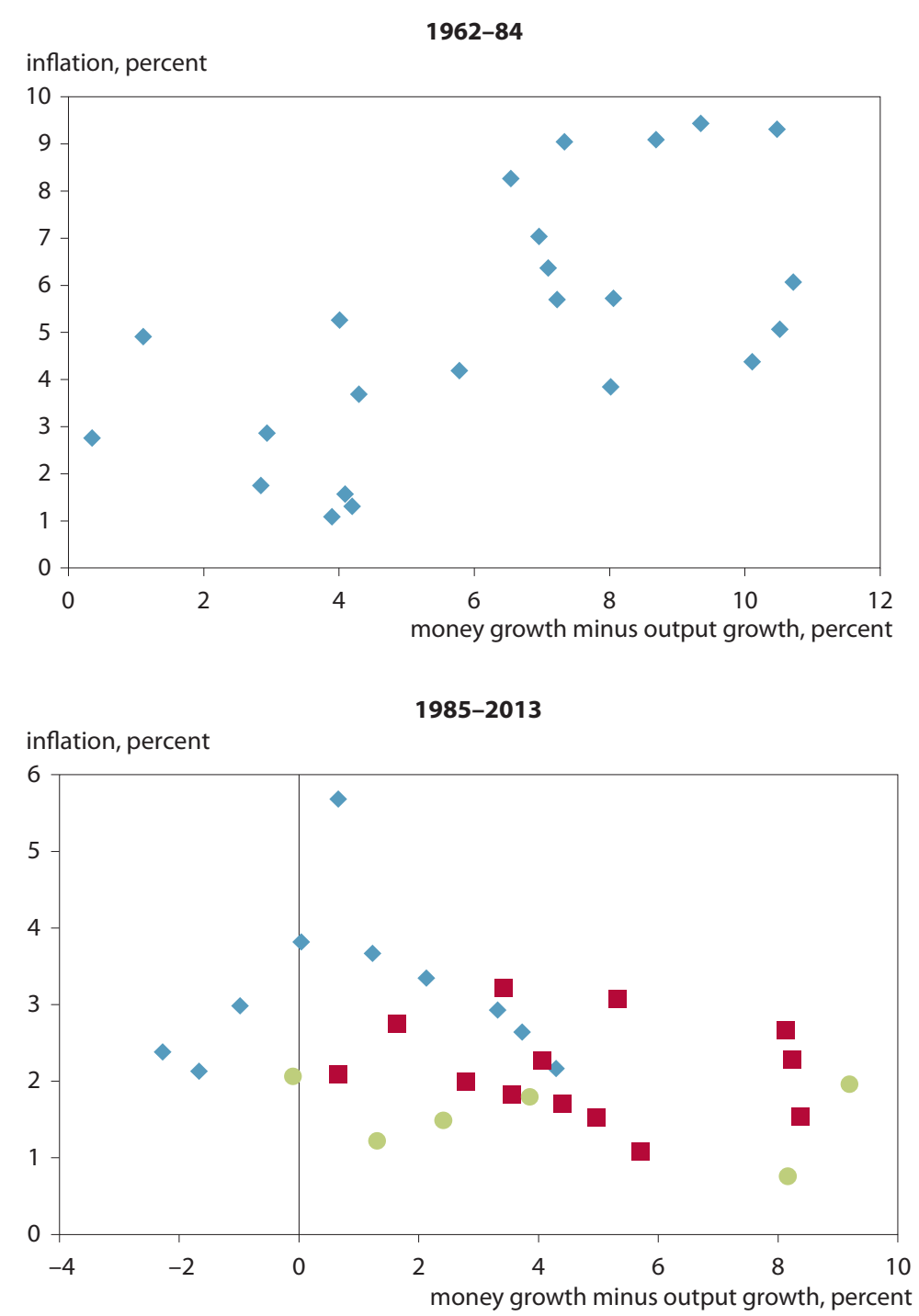

Note: Observations for different time periods are identified as: diamonds for 1985-94; squares, 1995-2007; and circles, 2008-13.

Sources: International Monetary Fund (IMF 2015a) and author's calculations.

An important caveat to the seeming demise of the quantity theory after the mid-1980s is that other major industrial countries do not seem to show the same decisive reversal as in the United States. As shown in the scatter diagrams and regression results in appendix A (figure A.1 and table A.1), moderate support for the theory is still found in Australia, France, and (ironically) Japan in the period subsequent to 1985. In these cases, statistically significant coefficients on the order of 0.4 to

demand for money. Otherwise the field of 1995-2006 observations (squares, figure 1) is relatively flat, around 2 percent inflation, suggesting that by then the phenomenon of surprise disinflation would have been exhausted.
0.5 relate inflation to the excess of money growth over output growth (listed in table A. 1 as moderate support for the quantity theory). ${ }^{12}$ Milder but still statistically significant support is also found in Canada and the United Kingdom in this period (coefficients of about 0.2 ). This degree of support is also found in euro area data, but not if a dummy variable is allowed to capture the fall in inflation after the Great Recession, in which case the coefficient on excess money growth collapses to near zero. ${ }^{13}$

12. Strong, full support for the theory would require the coefficient to be unity, not attained even in the United States in 1962-84.

13. The observation for 2015 for the euro area applies the IMF (2015b) 


\section{Figure 2 Comparison of Federal Reserve liabilities and bank reserves, 2001-14}
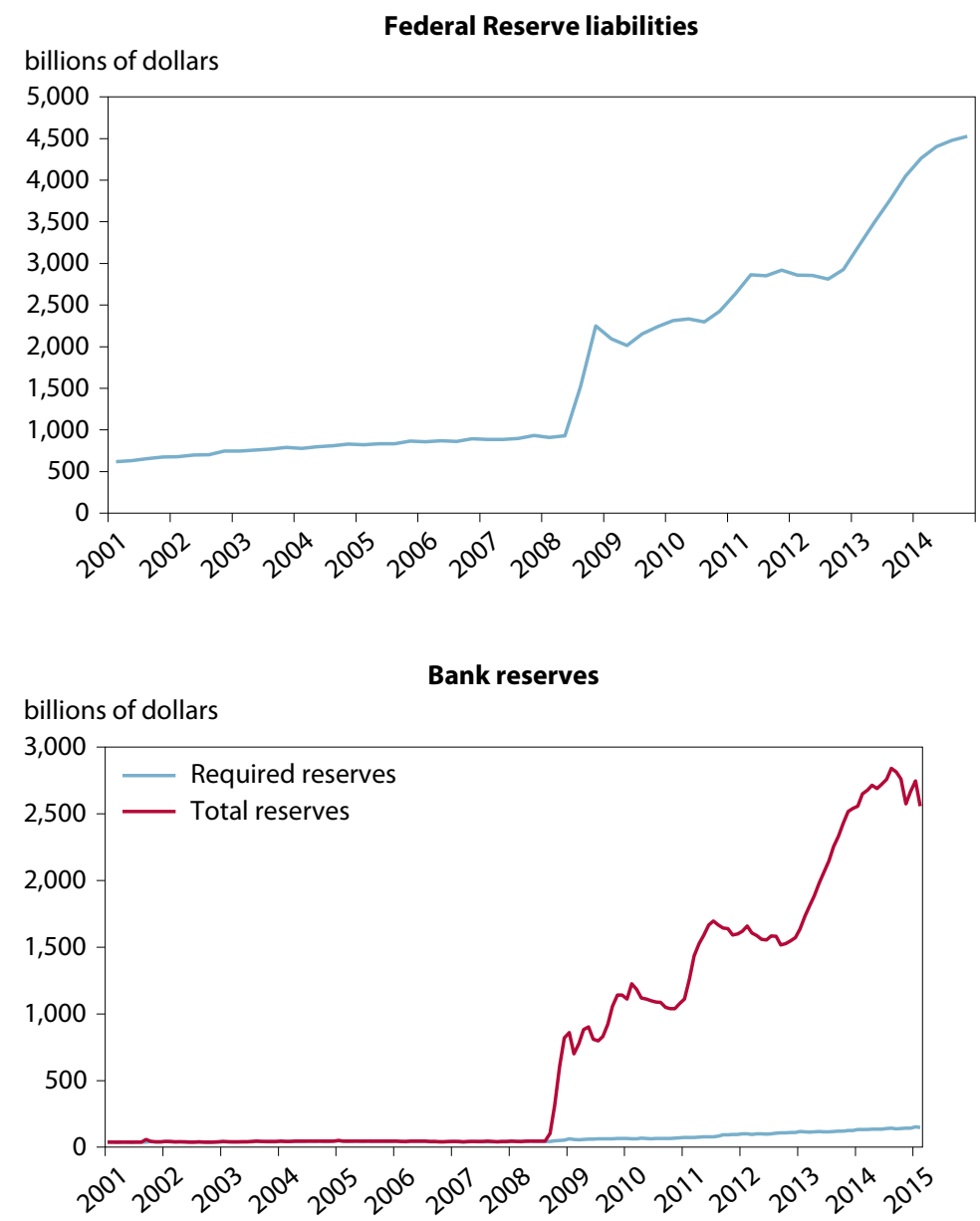

Sources: Federal Reserve (2015c, 2015d).

\section{PLUNGING MONEY MULTIPLIER, GRADUALLY FALLING VELOCITY}

Quantitative easing has indeed caused a surge in one narrow money aggregate: the money base, which is the sum of currency plus bank reserves held at the central bank. Prior to QE, banks typically held no more than the required amount of reserves plus a modest amount for daily clearing. The reserve requirement is 10 percent of net transactions account balances in excess of $\$ 104$ million. ${ }^{14}$ Thus, at the end of 2007 , bank reserves at the Federal Reserve amounted to $\$ 43.5$ billion, of which $\$ 41.7$ billion were required reserves (Federal Reserve 2015c). In

estimate of growth, and for money growth uses the seasonally adjusted rate for the 12 months ending February (ECB 2015b).

14. The rate is 3 percent for $\$ 15$ million to $\$ 104$ million and zero below $\$ 15$ million. Net refers to deduction of amounts due from other depository institutions (Federal Reserve 2015f). comparison, total checkable deposits amounted to $\$ 792$ billion (Federal Reserve 2015d), placing the effective average required reserve ratio at 5.3 percent of gross checkable deposits.

As the Fed began to make large purchases of Treasury bonds and mortgage-backed assets, the proceeds of these purchases tended to wind up as excess reserves of banks, rather than being loaned out again by the banks. Figure 2 shows the balance sheet of the Federal Reserve in the top panel and total versus required reserves of member banks held at the Fed in the bottom panel. A key reason for the rise in excess reserves is that in October 2008 the Federal Reserve began paying interest on reserves (including required reserves). It currently pays an interest rate of 0.25 percent, whereas the 4-week Treasury bill rate in early April 2015 was only 0.02 percent (Federal Reserve 2015e). The change to payment of interest on reserves was a reform that had been long in the making, and as part of emergency legislation in the financial crisis its implementation was 
accelerated from the originally planned year of $2011 .{ }^{15}$ During the crisis, an additional incentive to holding excess reserves was that they constituted a form of risk-free liquidity in a period of sometimes extreme counterparty risk. ${ }^{16}$

As shown in figure 2, from the end of 2007 to the end of 2014 the balance sheet of the Federal Reserve rose from $\$ 930$ billion to $\$ 4.53$ trillion, an increase of $\$ 3.6$ trillion. Excess reserves of the banking system rose by $\$ 2.5$ trillion, amounting to about 70 percent of the total increase in the Fed's balance sheet. The sharp rise in excess reserves meant that bank lending was not the vehicle through which QE exercised a stimulative effect. Banks had potentially much more lending capacity but tended not to use it and to accumulate excess reserves instead. ${ }^{17}$

\section{A key reason for the rise in excess reserves}

\section{is that in 0ctober 2008 the Federal Reserve} began paying interest on reserves.

Quantitative easing had not been designed to work primarily through increasing bank lending and the money supply. The interest rate was already near the zero bound, and normal central bank purchases of government obligations would not have helped much. ${ }^{18}$ Instead, QE was designed to work by reducing the term premium (excess of the interest rate on long-term debt over that on short-term debt). This reduction was intended to reduce the cost of long-term capital and spur investment, boost the demand for riskier assets including equities, and, in the case of mortgage-backed assets purchased, stimulate a depressed part of the economy. QE did all of these things. ${ }^{19}$ As a side effect, it also caused a large increase in excess reserves of the banks. As another side effect, QE contributed

15. Federal Reserve (1993), and Federal Reserve, "Board announces that it will begin to pay interest on depository institutions' required and excess reserve balances," press release, October 6, 2008, www.federalreserve.gov/newsevents/ press/monetary/20081006a.htm (accessed May 1, 2015).

16. The phase-in of higher capital requirements against risk-weighted assets under Basel III may also have contributed an incentive for banks to shift assets toward risk-free excess reserves at the Federal Reserve.

17. Thus, total assets of commercial banks in the United States rose from $\$ 10.9$ trillion at the end of 2007 to $\$ 15.0$ trillion at the end of 2014, an increase of 38 percent. Their total credit outstanding rose from $\$ 8.9$ trillion to $\$ 10.9$ trillion, or by 22 percent. Their total loans and leases outstanding rose from $\$ 6.8$ trillion to $\$ 7.9$ trillion, or 16 percent (Federal Reserve 2015b).

18. Central bank purchases of government obligations are the normal means of injecting more money into the hands of the public, as households and firms deposit the proceeds. Central bank sales of government obligations are correspondingly the normal means of reducing money in the hands of the public.

19. From December 2008, when the first round of QE began, to April 2013, before the Federal Reserve announced it would begin to "taper" QE, the S\&P 500 index rose from 871 to 1598 (Bloomberg). to a needed downward adjustment in the dollar, which had become seriously overvalued as a consequence of the safe-haven effect at the height of the financial crisis (Cline and Williamson 2009)..$^{20}$

In a fractional reserve banking system, if there are no excess reserves, bank transactions deposits will be the multiple $1 / \mathrm{R}$ times reserves, where $\mathrm{R}$ is the reserve ratio. In the textbook formulation, money expansion occurs through a chain of deposits and new lending of the amounts not set aside in reserves. ${ }^{21}$ As a first approximation, the "money multiplier" relating the money supply to the money base would be expected to be on the order of $1 / \mathrm{R}$, or about 10 to $1 .{ }^{22}$ After taking account of time deposits, the total broad money supply will be an even larger multiple of the money base.

Beyond the influence of the required reserve ratio, however, the money multiplier will also be influenced by the interest rate, which is the opportunity cost of holding money. A high interest rate will discourage the public from holding currency, shrinking the money base and raising the money multiplier. As shown in figure 3, the money multiplier relating broad money to the money base reached as high as 16 in the early 1980s and was in the range of 12 to 14 in the early 2000s. The money multiplier had been lower in the 1960s and early 1970s, when inflation and interest rates were lower, and figure 3 shows a relatively close correlation of the money multiplier to the short-term interest rate from 1960 through 2000.

However, from the end of 2007 to the end of 2008 the money multiplier fell by half (from 14 to 7 ), and it continued to fall much further (to 4) by the end of 2014. So a collapse in the money multiplier has offset a sharp rise in the money base attributable to quantitative easing and the buildup of large excess reserves.

Because of the collapse in the money multiplier, the surge in Federal Reserve assets has not translated into a corresponding surge in broad money. As a consequence, velocity has not fallen much following quantitative easing, although it has continued a long-term gradual decline, as shown in figure 4.

20. From December 2008 to April 2013 the real trade-weighted index of the dollar fell by 9.9 percent (Federal Reserve 2015g).

21. Thus, after an initial deposit of $\$ 100$ in bank $A$, the bank sets aside $R$ times $\$ 100$ for reserves ( $\$ 10$ if $R=0.1$ ) and lends the rest. On the second round, bank B receives a deposit of $\$ 90$, sets aside $\$ 9$ in reserves, and lends $\$ 81$. By the 25th round, for example, the cumulative total of new deposits is $\$ 928$, nearly $1 / \mathrm{R}$ times the initial $\$ 100$.

22. At the end of 2007 , currency outside the banks was $\$ 774$ billion, about the same size as the $\$ 792$ billion in checkable bank deposits (Federal Reserve 2015d). The fact that the money base including currency was about twice the size of checkable deposits approximately offset the fact that the effective average reserve ratio was only about 5 percent instead of the marginal 10 percent in determining the money multiplier. 


\section{Figure 3 Ratio of broad money to the money base and three- month Treasury bill rate}

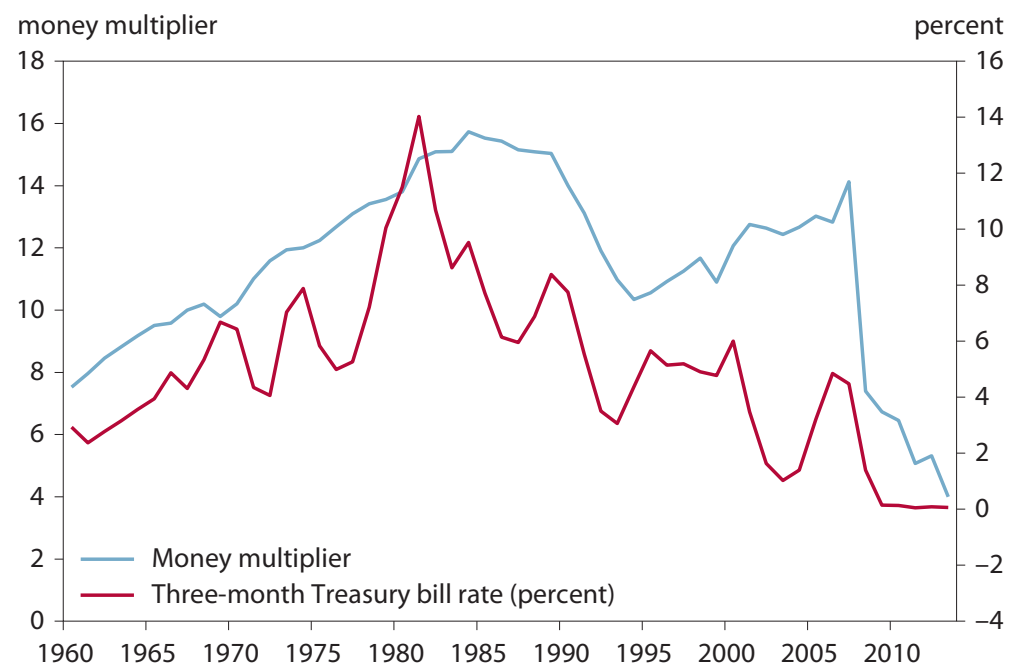

Sources: Federal Reserve (2015e), International Monetary Fund (IMF 2015a), and author's calculations.

Figure 4 Ratio of nominal GDP to broad money (velocity)

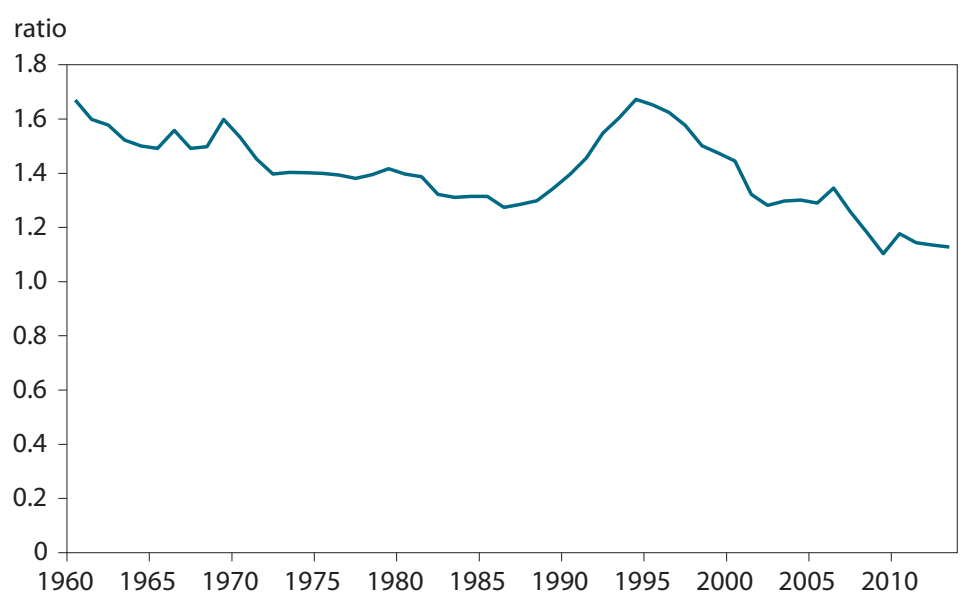

Sources: International Monetary Fund (IMF 2015a) and author's calculations.

In terms of the quantity equation, broad money $M$ can be written as the product of the money base $M B$ and the money multiplier $m m$ :

\section{1') $[M B \times m m] V=P Q$}

In the usual quantity equation (equation 1 discussed earlier) it is typically assumed that velocity $(V)$ is constant. As it turns out, velocity did remain much closer to constancy than might have been expected in the face of QE. For broad money, velocity did fall, but not by much: from 1.26 in 2007 to 1.13 in 2013, a decline of 10 percent.
In contrast, when the broad money stock $(M)$ is decomposed into the product of the money base $(M B)$ and the money multiplier $(\mathrm{mm})$, as in equation $1^{\prime}$, it becomes evident that it was a large drop in the money multiplier, not the velocity, that was the main reason for the absence of monetary inflation pressures that otherwise might have been associated with the sharp increase in the money base under QE. Thus, from 2007 to 2013 the money multiplier fell from 14 to 4 , a decline of 71 percent. Velocity did not collapse, but the money multiplier did. Correspondingly, the relevant broad money supply rose far less than would usually have been implied by the rise in the money base. 
MONEY MULTIPLIER, EXCESS RESERVES, AND INFLATIONARY POTENTIAL

Broad money rose from $\$ 1.15$ trillion at the end of 2007 to $\$ 1.49$ trillion at the end of 2013 , an increase of 30 percent. If banks had not built up large excess reserves, the money multiplier would not have fallen so precipitously, and the pace of broad money expansion would have been faster. Those who worry about future inflation as a legacy of quantitative easing would appear to be concerned primarily that as more normal conditions return, the reduction in excess reserves will prompt a rapid growth in broad money supply and facilitate inflation.

The FOMC has articulated plans for policy normalization (Federal Reserve 2015a). Such normalization means raising the federal funds rate and other short-term interest rates to more normal levels and reducing the Fed's holdings of securities. The FOMC has stated that it "intends to move the federal funds rate into the target range ... primarily by adjusting the interest rate it pays on excess reserve balances." The implication is that banks will be encouraged to maintain higher levels of excess reserves than they otherwise might, thereby cushioning the reduction and potential translation into broad money expansion that could occur as interest rates rise in the economy. The FOMC also intends to reduce Fed holdings of securities by ceasing the reinvestment of principal as securities mature. It does not currently plan to sell agency mortgage-backed securities. In short, the framework of normalization rests on the premise that proper adjustment of interest rates will keep future inflation under control, and that any expansion of monetary aggregates will correspondingly be moderate. By implication, the large excess reserves are not seen as a monetary time bomb or Damocles' sword but instead as manageable through the proper use of interest payments on excess reserves.

An underlying question about the future inflationary risk from unwinding of excess reserves is whether banks really control these reserves in the aggregate. Former Federal Reserve Vice Chairman Alan Blinder has argued in effect that the banks do control the reserves, and that eliminating the 0.25 percent paid on reserves would stimulate the economy by inducing them to "find other uses for the money ... [such as] buying shortterm securities [or] lending more, which is what we want." ${ }^{23}$ In contrast, some Federal Reserve economists essentially consider this view to be a fallacy of composition. Antinolfi and Keister ${ }^{24}$ argue that the amount of excess reserves is driven by the size of

23. Alan S. Blinder, "The Fed Plan to Revive High-Powered Money," Wall Street Journal, December 10, 2013.

24. Gaetano Antinolfi and Todd Keister, "Would Lowering the Interest Rate on Excess Reserves Stimulate the Economy?” Liberty Street Economics, New York: Federal Reserve Bank of New York, August 27, 2012. the assets held by the Federal Reserve, because the Fed's liabilities must equal its assets; so long as it holds large assets acquired under $\mathrm{QE}$, the system as a whole will have correspondingly large excess bank reserves, regardless of the interest rate paid on them. ${ }^{25}$ But this accounting identity argument does not take into account the fact that the same total of Fed liabilities could be maintained from a shift from excess reserves to required reserves if there were a wave of bank lending activity (such that the second bank itself increases lending in response to deposits from new loans by the first bank, rather than placing funds into excess reserves). ${ }^{26}$

A crucial feature of the large excess reserves resulting from quantitative easing is that it would not be possible to prevent their being drawn down by imposing far higher reserve requirements. Under legislation dating back to 1980, the Federal Reserve is prohibited from raising the reserve requirement higher than 14 percent (Federal Reserve 1993, 578). The increment in required reserves within this ceiling would amount to only a small fraction of total excess reserves. ${ }^{27}$ Moreover, the main historical experience of dealing with nascent inflation through a very large increase in the reserve requirement was not a happy one. ${ }^{28}$

In the most likely scenario, then, as the economy returns to more normal conditions, the Federal Reserve would raise interest rates, and the proximate vehicle it would use to transmit the desired rate would be the interest rate paid on reserves. Banks would then link their lending rates to the newly higher rate received on reserves, because that rate would be the opportunity cost of funding for lending. In a more problematical scenario, however, there could conceivably be a major swing in the economic environment from risk-off to risk-on behavior, causing a strong tendency of banks to draw down excess reserves

25. Thus, in particular, if one bank runs down its excess reserves, it makes loans that wind up as deposits in another bank, potentially increasing the second bank's excess reserves, unless the Federal Reserve reduces its assets.

26. See for example Bob McTeer, "Bank Reserves: A Hot Potato," Forbes, May $22,2013$.

27 . Required reserves are only about $\$ 150$ billion, out of total reserves of about $\$ 2.6$ trillion (Federal Reserve 2015c). At the end of 2014, total checkable deposits were about $\$ 2.0$ trillion (Federal Reserve 2015d). Even if all banks were at or beyond the threshold where the current 10 percent marginal reserve ratio applies, the extra 4 percent of checkable deposits at the legal limit of 14 percent would lock in only about an additional $\$ 80$ billion, or only about 3 percent of excess reserves.

28. In 1936 the Federal Reserve raised reserve requirements from 13 to 26 percent on transactions deposits and from 3 to 6 percent on time deposits, because it was concerned about inflationary potential from the buildup of excess reserves to more than 50 percent of total reserves (far below the ratio today) (Wheelock 2009, 1). Confronted by higher reserve requirements, banks responded by reducing lending in order to reduce deposits and required reserves. Growth of the money stock fell as a consequence, from a year-overyear rate of about 12 percent in early 1936 to about -3 percent by early 1938 . The intervention to preempt inflationary expansion of money turned out to be excessive, contributing to the $1937-38$ recession. 
in order to expand loans. If the Federal Reserve were reluctant to apply sizable interest rate increases in a short period of time, there could be a substantial rundown in the excess reserves and expansion of money supply. In the past, the Fed has tended to adjust the rate in relatively slow increments. The most rapid increase in the past quarter-century was from December 1993 to April 1995, over which period the rate rose by a total of about 300 basis points. However, the Federal Reserve might also aggressively use its term deposit facility, established in 2010, as a means of retaining excess reserves, as well as reverse repurchase operations for the same purpose (Federal Reserve 2015h).

An alternative type of adverse scenario could arise if there were political pressure to hold down interest rates because of concern about the interest costs of public debt. Limits to the interest rate on excess reserves under these circumstances could contribute to a rebound in the money multiplier. Implicitly, higher inflation would be welcomed as a means of alleviating the burden of public debt, but there would be the chance that inflation could get out of hand.

\section{CONCLUSION}

On balance, the risk of severe inflation resulting from the buildup of the balance sheet of the Federal Reserve in association with quantitative easing seems low. To begin with, the US economy has not experienced inflation driven by excessive money expansion since at least the mid-1980s (figure 1). Indeed, the rising demand for money, as the opportunity cost of holding money fell with lower inflation, has meant that over the past three decades there has been a tendency for faster money growth (relative to real GDP) to be associated with lower rather than higher inflation. The supply-focused quantity theory of money broke down. The pattern associating rapid money growth with low inflation since the mid-1980s would require a sharp reversal for money supply to become the proximate cause of inflation. In the meantime, it seems fair to say that in the United States inflation is determined by labor market and product market tightness (in the Phillips curve tradition), and that the opposing proposition that "inflation is always and everywhere a monetary phenomenon" (Friedman's summary of the quantity theory) does not hold in a narrow sense relating to money supply. ${ }^{29}$

29. It is a separate matter whether US labor market tightness has reached the point where interest rates should be raised, as argued for example by Martin Feldstein, "The Fed Needs to Step Up Its Pace of Rate Increases," Wall Street Journal, March 30, 2015.
A second important phenomenon is that inflation has remained low despite a large buildup in the Fed's balance sheet not because the velocity of broad money has collapsed, but because the money multiplier has done so. Because of a large increase in excess bank reserves equal to nearly three-fourths of the increase in the Federal Reserve's total assets, the usual money multiplier (inverse of the reserve requirement ratio) no longer holds. Broad money was 14 times the money base in 2007; by end-2014 it was only 4 times the money base.

\section{Inflation has remained low despite}

\section{a large buildup in the Fed's balance sheet not because the velocity of broad} money has collapsed, but because
the money multiplier has done so.

A third observation is that arguably this same phenomenon could pose a risk of inflationary money expansion when and if banks start to draw down excess reserves.

Fourth, the principal implication for policy purposes is that the Federal Reserve will need to be particularly adept in avoiding any inflationary pressures that might develop from the unwinding of large excess bank reserves as more normal monetary conditions return. The Fed has clearly given considerable attention to this task and at present plans to use higher interest rates on excess reserves as needed to control such pressures. Indeed, the authority to pay interest on reserves is what will enable the Fed to raise rates when necessary, because otherwise an incipient rise in the short-term interest rate would quickly be choked off as banks ran down excess reserves to take advantage of the higher interest rates.

Fifth, because quantitative easing constitutes navigating in uncharted waters, there is some non-zero probability that inflation could nevertheless still be the consequence of potential money supply expansion resulting from QE. 


\section{REFERENCES}

Bernanke, Ben S. 2006. Monetary Aggregates and Monetary Policy at the Federal Reserve: A Historical Perspective. Speech at the Fourth ECB Central Banking Conference, Frankfurt, Germany. Available at: www.federalreserve.gov/newsevents/speech/bernanke20061110a.htm (accessed April 28, 2015).

Blaug, Mark. 1968. Economic Theory in Retrospect. Homewood, IL: Richard D. Irwin.

Cline, William R., and John Williamson. 2009. 2009 Estimates of Fundamental Equilibrium Exchange Rates. Policy Briefs in International Economics 09-10 (June). Washington: Peterson Institute for International Economics.

Congdon, Tim. 2006. Broad Money vs. Narrow Money: A Discussion Following the Federal Reserve's Decision to Discontinue Publication of M3 Data. LSE Financial Markets Group Special Paper 166 (May). London: London School of Economics.

ECB (European Central Bank). 2015a. Strategy. Frankfurt.

ECB (European Central Bank). 2015b. Euro Area Monetary Aggregate M3: Annual Growth Rates. Statistical Data Warehouse. Frankfurt.

Federal Reserve. 1993. Reserve Requirements: History, Current Practice, and Potential Reform. Federal Reserve Bulletin (June): 569-89. Washington.

Federal Reserve. 2015a. Policy Normalization Principles and Plans. Washington.

Federal Reserve. 2015b. Assets and Liabilities of Commercial Banks in the United States (H.8). Washington.
Federal Reserve. 2015c. Reserves of Depository Institutions (H.3). Washington.

Federal Reserve. 2015d. Financial Accounts of the United States (Z.1) (March). Washington.

Federal Reserve. 2015e. Selected Interest Rates (H.15). Washington.

Federal Reserve. 2015f. Reserve Requirements. Washington.

Federal Reserve. 2015g. Foreign Exchange Rates (H.10). Washington.

Federal Reserve. 2015h. Term Deposit Facility. Washington.

Federal Reserve. 2015i. Why Does the Federal Reserve Aim for 2 Percent Inflation Over Time? Current FAQs. Washington.

Federal Reserve Bank of San Francisco. 2003. How Did the Fed Change Its Approach to Monetary Policy in the Late 1970s and Early 1980s? (January). San Francisco.

Federal Reserve Bank of St. Louis. 2015. Personal Consumption Expenditures: Chain-type Price Index. FRED Economic Data. St. Louis.

IMF (International Monetary Fund). 2015a. International Financial Statistics (monthly). Washington.

IMF (International Monetary Fund). 2015b. World Economic Outlook Database, April 2015. Washington.

Sargent, Thomas J., and Paolo Surico. 2011. Two Illustrations of the Quantity Theory of Money: Breakdowns and Revivals. American Economic Review 101 (February): 109-28.

Thornton, Daniel L. 2010. The Downside of Quantitative Easing. Economic Synopses, no. 34. Federal Reserve Bank of St. Louis.

Wheelock, David C. 2009. How Not to Reduce Excess Reserves. Monetary Trends (September). Federal Reserve Bank of St. Louis.

This publication has been subjected to a prepublication peer review intended to ensure analytical quality. The views expressed are those of the author. This publication is part of the overall program of the Peterson Institute for International Economics, as endorsed by its Board of Directors, but it does not necessarily reflect the views of individual members of the Board or of the Institute's staff or management.

The Peterson Institute for International Economics is a private nonpartisan, nonprofit institution for rigorous, intellectually open, and indepth study and discussion of international economic policy. Its purpose is to identify and analyze important issues to make globalization beneficial and sustainable for the people of the United States and the world, and then to develop and communicate practical new approaches for dealing with them. Its work is funded by a highly diverse group of philanthropic foundations, private corporations, and interested individuals, as well as income on its capital fund. About 35 percent of the Institute's resources in its latest fiscal year were provided by contributors from outside the United

States. A list of all financial supporters for the preceding four years is posted at http://piie.com/supporters.cfm. 
APPENDIX A EVIDENCE ON THE QUANTITY THEORY OF MONEY IN OTHER INDUSTRIAL COUNTRIES

Figure A.1 Inflation versus excess of broad money growth over output growth (Canada, United Kingdom, Japan, Australia, Germany, France, euro area)

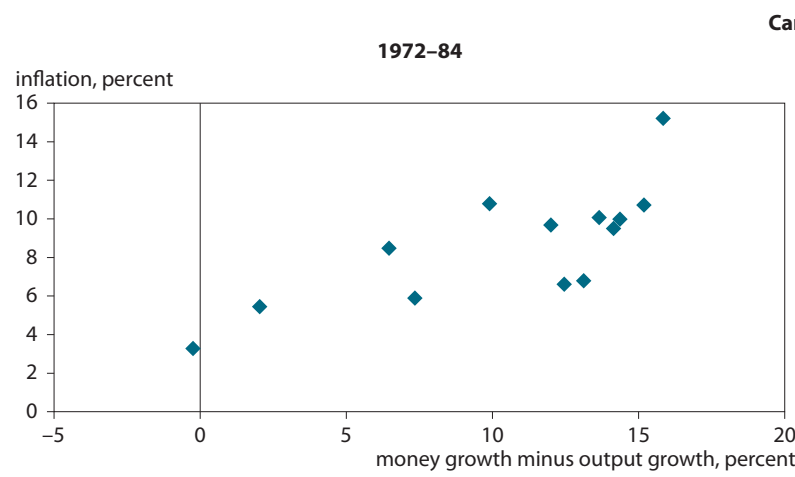

Canada
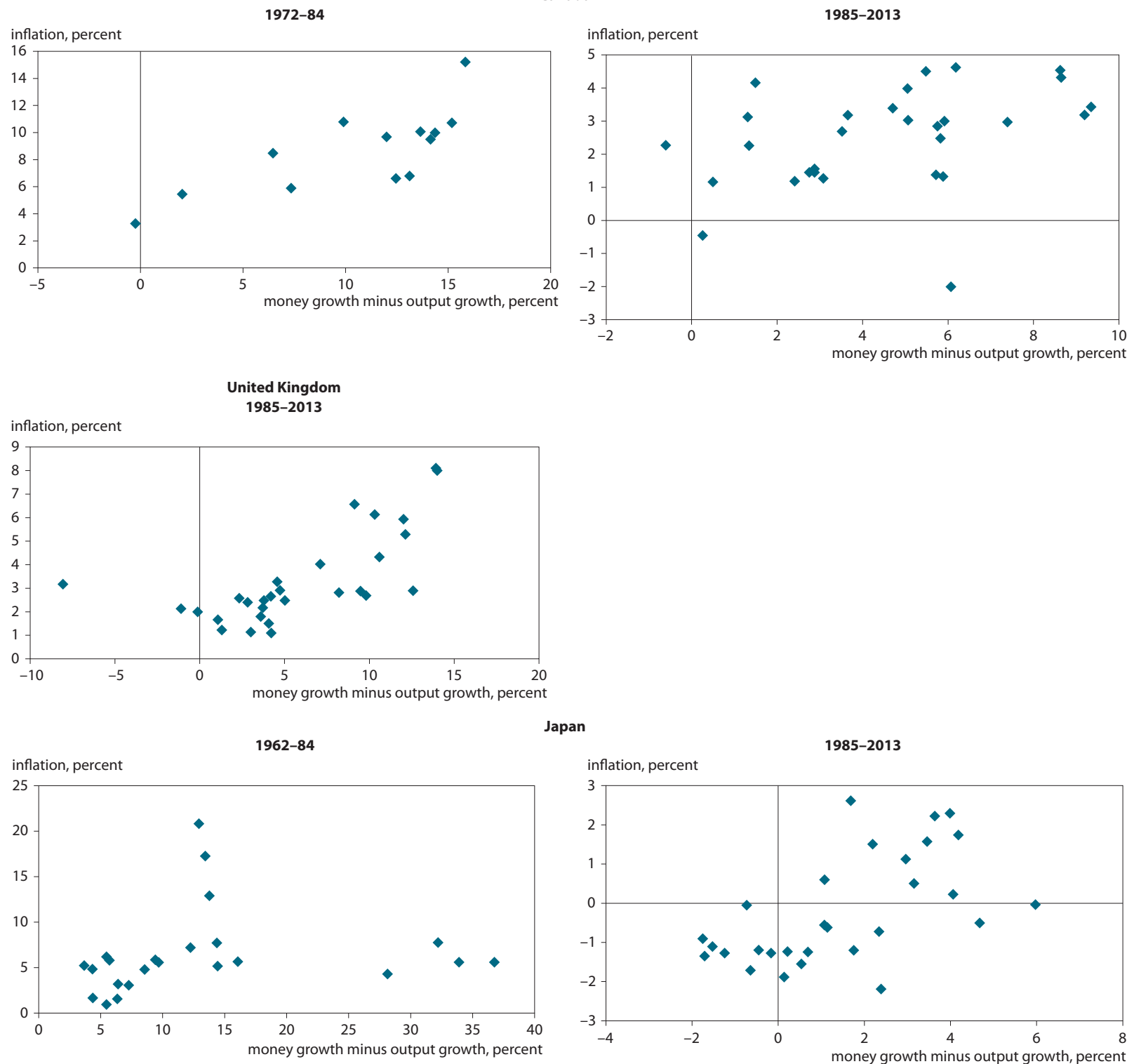

Japan

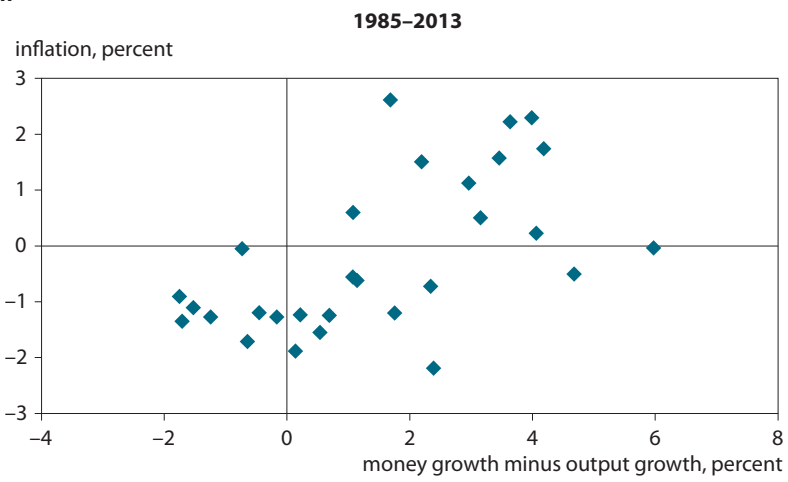

(continues) 
Figure A.1 Inflation versus excess of broad money growth over output growth (Canada, United Kingdom, Japan, Australia, Germany, France, euro area) (continued)

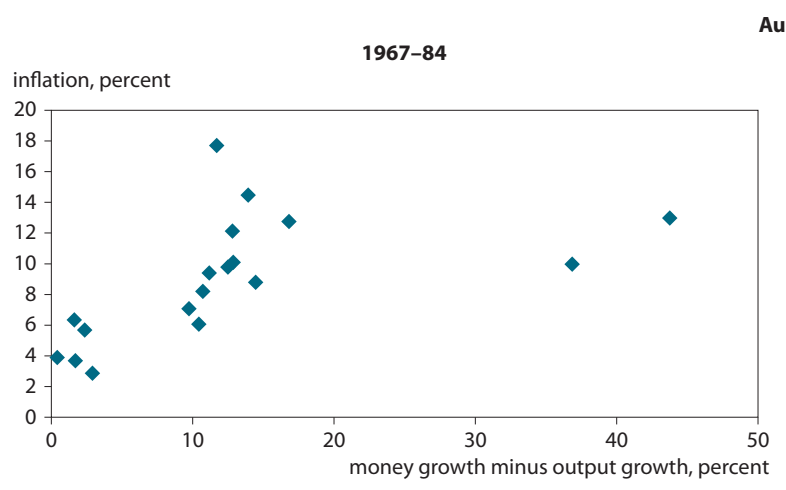

Australia
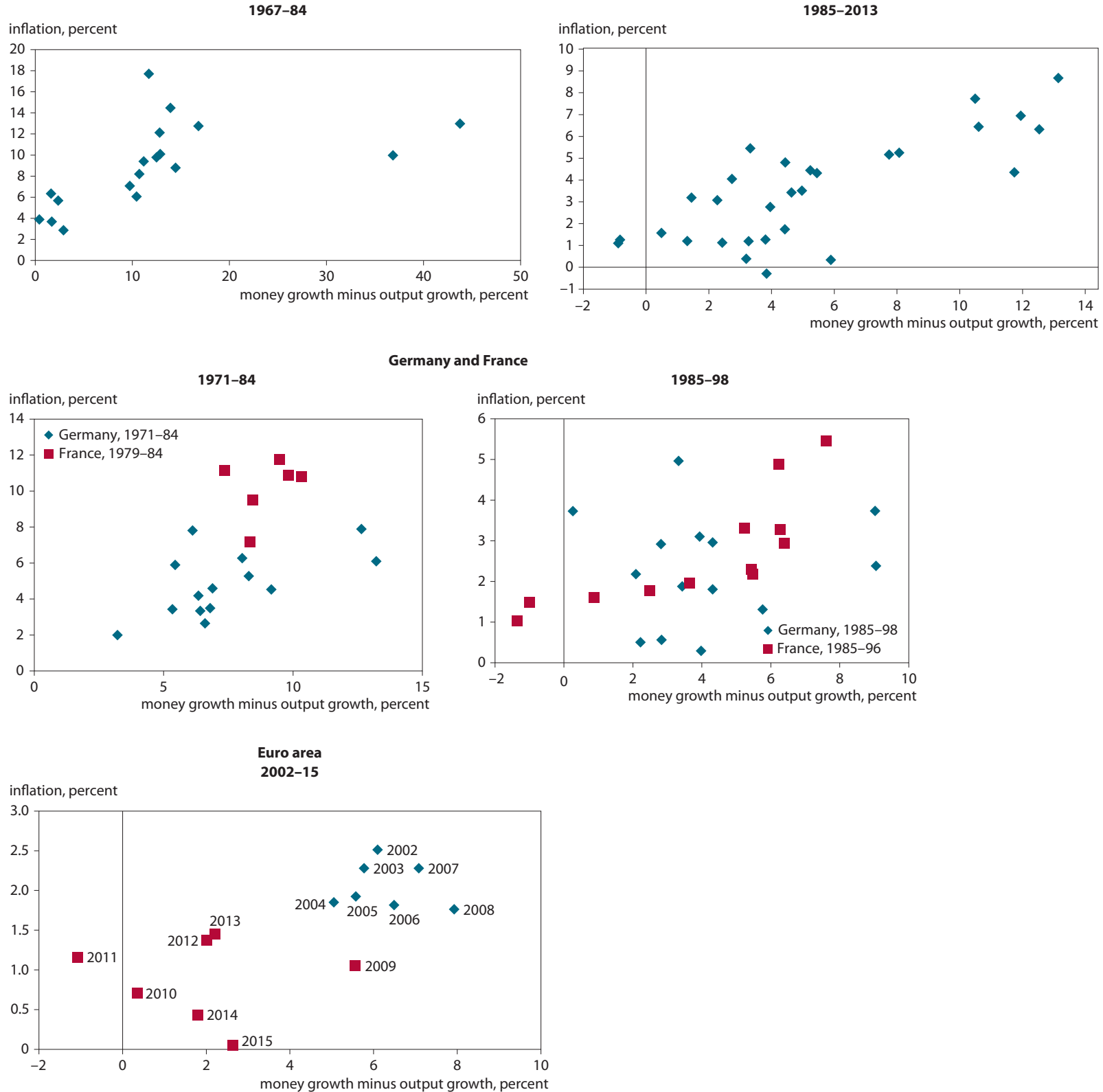

Sources: International Monetary Fund (IMF 2015a, b), European Central Bank (ECB 2015b), and author's calculations. 
Table A.1 Regressions of inflation on money growth minus real GDP growth

\begin{tabular}{lcccccc}
\hline & Year & $\begin{array}{c}\text { Intercept } \\
\text { (percent) }\end{array}$ & Coefficient & t-statistic & $\begin{array}{c}\text { Adjusted } \\
\mathbf{R}^{2}\end{array}$ & $\begin{array}{c}\text { Support for quantity } \\
\text { theory of money }\end{array}$ \\
\hline Period I & & & & & & \\
Australia & $1967-84$ & 6.58 & 0.19 & 2.6 & 0.25 & mild \\
Canada & $1972-84$ & 3.88 & 0.45 & 3.9 & 0.54 & moderate \\
Germany & $1971-84$ & 1.87 & 0.39 & 2.5 & 0.3 & moderate \\
Japan & $1962-84$ & 5.46 & 0.07 & 0.7 & -0.02 & none \\
Period II & & & & & & moderate \\
Australia & $1985-2013$ & 1.03 & 0.47 & 6.4 & 0.58 & mild \\
Canada & $1985-2013$ & 1.53 & 0.21 & 2.2 & 0.12 & moderate \\
France & $1985-96$ & 1.26 & 0.36 & 4.2 & 0.6 & none \\
Germany & $1985-98$ & 2.11 & 0.05 & 0.3 & -0.08 & moderate \\
Japan & $1985-2013$ & -0.78 & 0.38 & 3.7 & 0.31 & mild \\
United Kingdom & $1985-2013$ & 1.78 & 0.26 & 4.9 & 0.45 & mild \\
Euro area -1 & $2002-15$ & 0.74 & 0.18 & 3.1 & 0.4 & none \\
Euro area -2 & $2002-15$ & $2.2 ; 0.92$ & -0.01 & -0.19 & 0.64 & \\
\hline
\end{tabular}

a. Dummy variable after 2008.

Source: Author's calculations. 